\title{
Using Literature as a Tool for Teaching English Language: Animal Farm in the EFL Classroom
}

\author{
Hintsa Teklehaimanot Asefa
}

(M.A in English Literature), Department of English language and Literature, Adigrat University, P.O.Box.50, Adigrat,Tigray, Ethiopia

\begin{abstract}
This article aimed at showing how literature can be used in language classes to develop student's knowledge of English. It has emphasized the use of literature as a popular technique for teaching EFL. First, the researcher examined the evolution of literature in the language classroom, then the researcher gave account of some reasons that justify its use in English as foreign language classes, of the role of reading in language development, and of the way novel is treated in the EFL classroom. Animal Farm is a good work to be used as a tool to develop student's communicative competence in English as a foreign language. The article ends with a didactic proposal of activities for EFL instruction based on the novel under discussion. Teaching English language is a necessity in today's world. Finding innovative ways to teach English is the need of the hour. One of the best practices of teaching English is through literature, which is quiet effective and amusing. This practice does not include the tedious way of teaching English through grammar. The paper discusses novel as a genre of literature through which English language can be taught. The study also includes discussions on the text, "Animal Farm".
\end{abstract}

Keywords: Literature and language teaching, EFL, Animal Farm, reading

\section{Introduction}

This paper has examined the relevant role of literature as a resource for teaching English as a foreign language. Here the focus was on the use that language teachers may make use of the modernist text, "Animal Farm", in order to help students develop their proficiency in English as a foreign language classroom. Literature supplies many linguistic opportunities to the language learner and allows the teacher to design activities that are "based on material capable of stimulating greater interest and involvement" than many other non-literary, informative texts (Carter and Long 1991: 3 ). The aim of these activities should be to focus on the form and content of the text at stake, and to provide the stimulus for interaction to take place between the learners among them, and with the teacher (Duff and Maley 1990: 3).

This paper is framed within the communicative approach to language teaching. This signifies that the development of communicative competence should be the last aim of any language activity. The relevance of literature in this approach is, on the one hand, that it transmits messages. In addition, it is a way of communication between the author and the reader. On the other hand, literature pays special attention to form, and this helps the learner reflect about language, another principle and goal of the communicative method. It is important that the learners develop their linguistic competence by learning how to express meanings in English, but also that they develop their communicative competence, that will allow them to transmit messages, to use the language to interact, to communicate with other people, which is, in the end, the basic function of language. The use of literature as a teaching tool is legitimated by the facts mentioned above, namely, because it provides with authentic linguistic (also sociolinguistic) and cultural material, and because it motivates the learners to interact. Thus, the place of literature as a tool rather than an end in teaching English as a foreign language is examined.

\subsection{Statement of the Problem}

Literature and language are closely related and this is a fact no one can deny. Literature is constituted by language and it represents one of the most recurrent uses of language. Language and linguistic analysis can also be employed to access literature from the learner's point of view. Brumfit and Carter (1986: 1) already emphasized the role of literature as "an ally of language". This technique is by no means novel, since literature has been a widely used teaching tool in different language teaching methods. However, here the perspective changes giving more relevance to the literary text as a work of art. First of all, the researcher goes over the changing role of literature in the tradition of foreign language teaching to end with an account of its current situation within the communicative approach.

In the grammar translation method, literature was the central component. Literary texts of the target language were read and translated, used as examples of good writing and "illustrations of the grammatical rules" (Duff and Maley 1990: 3). The focus of this teaching method was on form, on learning the rules of grammar and the lexical items as they appeared in the text. There was no literary interest, nor interest on content. After this method fell in disuse, literary texts also went forgotten for teachers of foreign language.

For the structural approaches to language teaching, literature was discredited as a tool, because it represented the old tradition. The functional-notional method ignored literature, because in this method the importance lies on communication and they present authentic language samples. Literature was not considered either to have a communicative function or to be authentic example of language use.

Nonetheless, in the last decade or so the interest in literature as one of the most valuable language teaching resources available has revived remarkably (Duff and Maley 1990: 3). Literature reading is, no doubt, a communicative activity and 


\section{International Journal of Science and Research (IJSR) \\ ISSN (Online): 2319-7064}

Index Copernicus Value (2015): 78.96 | Impact Factor (2015): 6.391

literary texts are who could nowadays deny such thing, authentic examples of language use. Many authors, among them Brumfit and Carter (1986) and Lazar (1993), reject the idea of the existence of a specific literary language and claim that the language used in literary texts is common language with a high concentration of linguistic features like metaphors, similes, poetic lexis, unusual syntactic patterns, etc. (see Lazar 1993: 7 for a more detailed account of the characteristics of the literary use of language). Because of all the above reasons, the researcher interested to carry out a study on using literary text in teaching English as a foreign language.

\subsection{Objectives of the Study}

The paper has the following specific objectives:

1) To examine how activities should be designed from literary texts in teaching EFL

2) To assess the relevance of employing novel in teaching English as a foreign language

3) To identify the reasons for using literary texts in EFL classroom.

\subsection{Research Methodology}

The study has employed qualitative method to show how literary texts could be analyzed and how the EFL teachers should approach to a selected literary text in English as foreign Language classroom. The literary text that the researcher has chosen belongs to the modernist tradition, and has never been used in the EFL classes as a language teaching resource. The novel Animal Farm is very much adequate for teaching due to its high pedagogic potential both as regards its content and its form. The modernist ideas and philosophy underlying the novel result of an extremely high interest for learner, who may very well feel identified with the novelist or narrator of the novel.

This paper is divided into three main sections. The first one is theoretical and explains the use that of literature in general and of novel in particular, is being made as a resource for foreign language teaching. The second section deals with the examination of the reasons why the novel by George Orwell Animal Farm is thought to be appropriate for such an approach. The final section is practical and collects a number of suggestions for classroom activities to be carried out with the novel to enhance language learning as well as literary awareness.

\subsection{Delimitation of the Study}

The study is delimited to looking at using literature in English as foreign language classroom. In order to propose for EFL teachers how activities could be designed from a literary text, the study is limited in one selected novel (i.e. Animal Farm). However, the study could also be applied to other genres of literature like drama, short story and poetry that are rich in language, literary devices and pedagogic.

\subsection{Significance of the Study}

The study will mainly benefit EFL teachers for selecting appropriate literary texts and how to design classroom activities based on the aim and objective of the lesson to be taught. In another way, it can influence EFL teachers to employ literary texts in their classrooms. In addition to this it can give an insight for researchers' who are interested to study on how literature can be used as an instrument for language teaching and learning at different grade levels. The study can also help EFL learners to appreciate literary texts and learn English language creatively.

\section{Review of Related Literature}

\subsection{Literature in Language Teaching}

\subsubsection{Literature and the Teaching of Language Skills}

Literature plays an important role in teaching four basic language skills like reading, writing, listening and speaking. However, when using literature in the language classroom, skills should never be taught in isolation but in an integrated way. Teachers should try to teach basic language skills as an integral part of oral and written language use, as part of the means for creating both referential and interactional meaning, not merely as an aspect of the oral and written production of words, phrases and sentences.

As Obediat (1997:32) states, literature helps students acquire a native-like competence in English, express their ideas in good English, learn the features of modern English, learn how the English linguistic system is used for communication, see how idiomatic expressions are used, speak clearly, precisely, and concisely, and become more proficient in English, as well as become creative, critical, and analytical learners. Custodio and Sutton (1998:20) explain that literature can open horizons of possibility, allowing students to question, interpret, connect, and explore. In sum, literature provides students with an incomparably rich source of authentic material over a wide range of registers.

Practitioners understand that language is best acquired from interesting comprehensible input that is within meaningful contexts (Krashen, 1982). It has long been advocated that grammar is best acquired intuitively by listening to speech and good literature, by reading, or by engaging in meaningful conversations before rules of grammar are learned (Darian, 1972). Based upon these assumptions, the paper suggested literary instructional activities that provide comprehensible input (Krashen, 1982), develop intuitive English speech patterns, and benefit reading development (Adams,1990; Short \& Harste, 1996). The evidence presented here suggests that meaningful instruction married to quality literature for EFL learners can be an effective approach to foreign language learning.

\subsection{Literature and Reading}

EFL teachers should adopt a dynamic, student-centered approach toward comprehension of a literary work. In reading lesson, discussion begins at the literal level with direct questions of fact regarding setting, characters, and plot which can be answered by specific reference to the text. When students master literal understanding, they move to the inferential level, where they must make speculations and interpretations concerning the characters, setting, and theme, 


\section{International Journal of Science and Research (IJSR) \\ ISSN (Online): 2319-7064}

Index Copernicus Value (2015): 78.96 | Impact Factor (2015): 6.391

and where they produce the author's point of view. After comprehending a literary selection at the literal and inferential levels, students are ready to do a collaborative work. That is to state that they share their evaluations of the work and their personal reactions to it - to its characters, its theme(s), and the author's point of view. This is also the suitable time for them to share their reactions to the work's natural cultural issues and themes. The third level, the personal / evaluative level stimulates students to think imaginatively about the work and provokes their problemsolving abilities. Discussion deriving from such questions can be the foundation for oral and written activities (Stern 1991:332).

\subsection{Reading as an Aid for Language Development}

Underlying the claim to using literature to develop linguistic and communicative competence is the assumption that reading is one of the best ways of learning a language. Be it consciously or unconsciously, reading helps the second language learner acquire not only more vocabulary and more meanings and uses of the words already known (lexical competence), but it also contributes to develop syntactic knowledge (Brumfi t and Carter 1986). Krashen (1989) and Coady (1997) argues that it is through extensive reading, that learners acquire most of their vocabulary, and that instruction plays a rather insignificant role as the number of words learned is concerned. Paribakht and Wesche (1997) are also of the same opinion. For Grabe and Stoller (1997), reading contributes greatly to vocabulary development and also to listening comprehension.

Therefore, reading literature is positive in several ways. It presents with authentic and varied language material, it provides with contextualized communicative situations, real patterns of social interaction, and use of language (Collie and Slater 1987: 2), it highlights the central role of the learner in the learning process and stirs up interaction in the classroom, it motivates learners by allowing them to relate what is being read to their own experience since it calls on emotional responses (Collie and Slater 1987: 2), and it contributes largely to develop further reading skills like "deducing the meaning and use of unfamiliar lexical items", "understanding the communicative value (function) of sentences and utterances", "recognizing the script of a language", etc. (Grellet 1981: 4-5). Using literature to teach language not only contributes to a better linguistic understanding, a development of creative skills, and higher language proficiency, it also makes an important contribution to literary appreciation (Ramsaran 1983: 42).

\subsubsection{Shared Reading}

Shared reading refers to two or more people sharing the reading of a text. In an activity called echo or shadow reading, students are asked to read aloud along with the teacher. The teacher reads aloud at slow pace, but faster than the students can read by themselves. The students' reading should lag slightly behind the teacher's. This helps with learning pronunciation and phrasing. This technique is helpful even for advanced students, because of the word pronunciation support. Resist the temptation to stop at each unfamiliar word. Students should begin to cluster meaning into chunks or phrases. The ultimate goal is for the students to summarize an entire paragraph or page-length passage in their own words after one reading (Reid, 2002).

A follow-up activity for further development is shared sentence reading. The teacher reads one sentence, immediately followed by the student reading the same sentence. Do not translate individual words, but keep the translation general to the sentence. Focus students on just getting the gist of the story. At the end of each paragraph, the teacher should reread the paragraph aloud before continuing to the next. This facilitates a review the paragraph before moving the next. Repeat this set of activities. Encourage the more advance learners to give a general translation for the less advanced learners (Reid, 2002).

Once a book is completed using the above techniques, the teacher may read the book again out aloud, encouraging the students to follow along. Students should not worry about the details. They should focus on getting the general structure of the story and the normal flow and rhythm of English. An audiotape can be useful for this activity. It is often helpful to construct a chart of the events that take place in the story (Reid, 2002).

\subsubsection{Independent Reading}

Students should be given many opportunities to read independently. Materials should be selected that are at the students' independent English reading level. This means that the student recognizes $99 \%$ of the words and comprehends $90 \%$ of the passage content (McKenna \& Stahl, 2003). Reading levels are not immoveable ceilings. They vary with the readers' interests and expertise. If a reader is interested in extreme sports, the reading level will be higher when reading materials related to extreme sports (McCormick, 2007).

There are at least two ways to structure independent reading that maximize language development. The first is to provide a few questions for the reader to answer at periodic intervals through the text (Reid, 2002). These should be general questions that focus the reader on understanding the theme or the gist of the reading. It is important to craft the questions so the readers will be successful. The goal is to build reader confidence. Good questions might be: What has happened so far? Who are the main characters? Do you think the protagonist will succeed? Why? Challenge intermediate students slightly more with questions such as these: What obstacles has the protagonist faced in reaching the goal? What cause-and-effect relationships do you see (Reid, 2002)?

\subsection{Literature and Writing}

Literature can be a powerful and motivating source for writing in EFL, both as a model and as subject matter. Literature as a model occurs when student writing becomes closely similar to the original work or clearly imitates its content, theme, organization, and /or style. However, when student writing exhibits original thinking like interpretation or analysis, or when it emerges from, or is creatively stimulated by, the reading, literature serves as subject matter. Literature houses in immense variety of themes to

\section{Volume 6 Issue 1, January 2017




\section{International Journal of Science and Research (IJSR) \\ ISSN (Online): 2319-7064}

Index Copernicus Value (2015): 78.96 | Impact Factor (2015): 6.391

write on in terms of guided, free, controlled and other types of writing. Finding appropriate material for their writing classes is sometimes difficult for composition teachers since writing has no subject matter of its own. One benefit of having literature as the reading content of a composition course is that the readings become the subject matter for compositions. In a composition course whose reading content is literature, students make inferences, formulate their own ideas, and look closely at a text for evidence to support generalizations. Thus, they learn how to think creatively, freely and critically. Such training helps them in other courses which require logical reasoning, independent thinking, and careful analysis of the text (Spack 1985:719).

\subsection{Criteria for Selecting Suitable Literary Texts in Foreign Language Classes}

When selecting the literary texts to be used in language classes, the language teacher should take into account needs, motivation, interests, cultural background and language level of the students. However, one major factor to take into account is whether a particular work is able to reveal the kind of personal involvement by arousing the learners' interest and eliciting strong, positive reactions from them. Reading a literary text is more likely to have a long-term and valuable effect upon the learners' linguistic and extra linguistic knowledge when it is meaningful and amusing. Choosing books relevant to the real-life experiences, emotions, or dreams of the learner is of great importance. Language difficulty has to be considered as well. If the language of the literary work is simple, this may facilitate the comprehensibility of the literary text but is not in itself the most crucial criterion. Interest, appeal, and relevance are also prominent. Enjoyment; a fresh insight into issues felt to be related to the heart of people's concerns; the pleasure of encountering one's own thoughts or situations exemplified clearly in a work of art; the other, equal pleasure of noticing those same thoughts, feelings, emotions, or situations presented by a completely new perspective: all these are motives helping learners to cope with the linguistic obstacles that might be considered too great in less involving material (Collie and Slater 1990:6-7).

\subsection{Benefits of Using Novel in Language Teaching}

The use of a novel is a beneficial technique for mastering not only linguistic system but also life in relation to the target language. In novel, characters reflect what people really perform in daily lives. Novels not only portray but also enlighten human lives. Using novel in a foreign language class offers the following educational benefits:

- Develops the advanced level readers' knowledge about different cultures and different groups of people,

- Increases students' motivation to read owing to being an authentic material,

- Offers real life / real life like settings,

- Gives students the opportunity to make use of their creativity,

- Improves critical thinking skills,

- Paves the way for teaching the target language culture,

- Enables students to go beyond what is written and dive into what is meant,
Helton, C.A, J.Asamani and E.D.Thomas (1998:1-5)

expounds the educational benefits of novels as follows:

- -stimulates their imagination,

- helps students to identify the emotions of the characters so that they can learn how others cope with situations and problems similar to their own experiences,

- helps them master the skills that will enable them to acquire information, process this knowledge, identify problems, formulate alternatives, and arrive at meaningful, thoughtful, effective decisions and solutions,

- develops oral and written language skills,

- serves as a springboard for a multitude of holistic learning and critical thinking activities beginning with basic comprehension and writing,

- presents a unique way of teaching reading by getting students involved and excited about the reading process,

- motivates students to become a lifelong reader,

When selecting a novel to be used in the foreign language class, the language teacher should pay attention to whether the novel has an intriguing story that will be of interest to the entire class. Themes and settings captivating their imagination and exploring the human condition should be included in the nature of the selected novels. Novel should have a powerful, fast-paced plot and interesting, well delineated, memorable characters. The content of the novel should be suitable to students' cognitive and emotional levels. Specific themes and concepts being developed in class should also be incorporated within the novel.

When assessing comprehension, teachers may employ novel tests requiring students to develop the sub-skills of written language like spelling, handwriting, grammar, and punctuation. Essay type tests written by teachers help students to gradually improve their skills in writing and organizing material into paragraphs with acceptable sentence structure. The tests are made up of not only fact-based questions serving as a basis of evaluating comprehension but also open-ended questions developing critical thinking abilities. The open-ended questions enable students to predict outcomes, make comparisons and contrasts, and draw conclusions. Class discussions of each novel event should comprise the main idea and supporting details, including who, what, when, where, and how.

In sum, the use of novel is a very beneficial technique in today's foreign language classes. If selected carefully, using a novel makes the students' reading lesson motivating, interesting and entertaining. Though many students find reading a novel written in a target language difficult, boring, un-motivating, novel is a very effective way of building vocabulary and developing reading comprehension skills. It is through reading that students broaden their horizons, become familiar with other cultures, and hence develop their intercultural communicative competence, learning how to view the world from different perspectives. The result will be the possession of critical thinking and writing. 


\section{International Journal of Science and Research (IJSR) \\ ISSN (Online): 2319-7064}

Index Copernicus Value (2015): 78.96 | Impact Factor (2015): 6.391

\section{Why Animal Farm?}

The key to success in using literature in EFL class seems to me to focus in the literary works that are selected and fascinating for students. Animal Farm offers great pedagogical opportunities for its magnificent language and language use, and its controversial underlying philosophy.

\subsection{Content}

From the point of view of a content analysis, the novel displays a series of features that make it very fascinating for the language classroom. It is a novel of satire (literary work that ridicules injustice, stupidity, tyranny, etc.) in which the author attacks Stalinist Communism, as well as other despotic systems of government. Animal Farm may also be called an allegorical beast tale, a story similar to the beast fables of Aesop except that a beast tale does not state an obvious moral. An allegory is a literary work in which characters; events, objects and ideas have secondary or symbolic meanings.

The novel reveals a revolution by farm animals tired of working for a tyrannical and unfair farmer. The text's events mimic the Russian revolution by Lenin and his Bolshevik in 1917. At farm, the pigs - who are the cleverest of the animals- establish themselves as the new leaders. They use lies and manipulation to remain in power, and to exploit those below them. Orwell describes how the Communist dream in Russia quickly began to sour, as those at the helm of Stalin's new government quickly became corrupt- just like the leaders they had overthrown in the name of revolution.

Animal Farm can be read on three different levels. On its first level, it is an entertaining story about farm animals and their cruel overseers. Very young children can understand and enjoy the story at this level. On its second level, it is an allegory representing the Communist takeover Russia in 1917 and the subsequent perversion of the idealist goals of the revolutionaries. On its third level, Animal Farm is an allegory representing any movement- and the persons in that movement- that goes awry because of the corrupting lure of power. The novel allows for many interpretations, since it displays a series of ironical and symbolic parts which are for the reader to interpret basing on his/her own experience.

The novel, Animal Farm, is therefore, culturally and literary relevant, in consonance with the learner's cultural background. It is motivating, it allows for personal involvement and cultural enrichment. Learners can draw from the novel and relate it to their personal experience. They create their own story as they interact with it, and this interaction implies involvement in the reading of the novel.

\subsection{Form}

The novel may be used for several sessions over one or two weeks. It has the advantage that it tells many different stories within the frame of a longer story, a kind of "super story", and this can be exploited by developing multiple exercises that deal with each sub-theme and with the general theme. This novel organization and representation of experience is very motivating and will engage learners in genuine decoding of communicative meaning.

Its unusual associations of words (collocations) or the peculiar meanings attributed to some words or expressions: "Animals are equal

But some animals are

More equal than others (P: 92) can be used by the teacher to have the learner reflect on the nature of the foreign language and on the different purposes that can be achieved by modifying the regular word order, altering the expected meaning of a word or inventing new combinations of two lexical items (see Reeves 1994 for more examples and a further explanation of "linguistic alienation" and "linguistic attraction").

Another reason why the researcher chose to work with "Animal Farm" is that it is a contemporary work and therefore, its language is modern and understandable. It is a straightforward and easy to understand novel with an engrossing, fast moving plot and interjections of wit. As a satire, it uses hyperbole and irony often, and as an allegory it frequently employs symbolism and allusion. For example, Napoleon the pig symbolizes the communist dictator Joseph Stalin; his name is an allusion to the French general and emperor Napoleon Bonaparte (1769-1821). Therefore, the text employs literary devices that make it very interesting and appealing for the learners. Thus, a teacher can make them reflect about the purpose of using those literary devices and the effect achieved by this, helping them, thus, to develop their knowledge of critical use of language.

The researcher is aware of the linguistic and conceptual difficulty of the novel. The fact that there are difficult areas, that the learners can overcome, is challenging and motivating and it is a further incentive to read and work on the novel.

Literature can improve reading comprehension to a great extent, because reading proficiency rests on the interaction between reader and writer, interaction mediated by the text (McKay 1986: 192). The more motivating and enjoyable the text, the more intense, real and powerful the interaction will be (Brumfit and Carter 1986: 15). When reading Animal Farm, learners are communicating, deciphering meanings and reflecting on language and communication strategies in the foreign language, this is a "crucial factor in the development of language learning abilities" (Brumfit and Carter 1986: 14). Cassany (1999) goes a bit further and claims that reading aids develop writing abilities by spurring their own imaginative writing and by providing them with examples of language use.

\subsection{Proposal of Activities to Implement with the Novel, "Animal Farm".}

These activities are thought to be some guiding outline to work with the novel, "Animal Farm" as a language teaching resource. They are addressed to intermediate-advanced EFL learners of English at University level. Following Maley (1996) the researcher has divided the exercises into four main sections: responding, analyzing, writing, and experiment further. 


\section{International Journal of Science and Research (IJSR) \\ ISSN (Online): 2319-7064}

Index Copernicus Value (2015): 78.96 | Impact Factor (2015): 6.391

\subsubsection{Responding}

These are what traditionally have been called pre-reading activities:

1. Who was the founder of Marxism- communism?

2. What are the socio-economic principles of socialism/ communism?

3. What is the basic difference between the economic policy of socialist and capitalist countries?

4. What do we mean by: Oppression and exploitation Social revolution? Corruption? Solidarity of struggle? Slogan or commandment? Political allegory? Cold war?

5. Deducing from the title. What do you think the novel is about? Work in pairs. Here we may expect answers such as: life of wild animals, bad treatment to other people, ineffective leadership, farmers' life, and so on.

6. With your partner, think of a general context out of which such a novel could have come to be: country, epoch, personal situation of the novelist, economic and political happenings, etc. For example, learners may think of a family who do have unfair distribution of materials or money and who always make conflict. With these initiating activities, the teacher smoothes the path of the reading exercise and guides the learners to what they will be dealing with the next days. It is important the learners predict what will come and that they have some previous idea of what they are going to read. This is a very important strategy not only in language learning, but also communication (Maingay 1983).

7. Read the novel at home. Here the students are supposed to read the text independently. So, the teacher is influencing his/her students to develop independent reading.

\subsubsection{Analyzing}

The activities in this section lead to a deeper analysis of the novel both as content and form are concerned: local and global vision.

\section{General Comprehension Question (global approach).}

1. What is the novel about? Where is it set? What is the central theme of each of the chapters of the novel? Here the teacher should provide the learners with some kind of background information about the general year reference of the novel and the events that were taking place in Russia at that time. Providing background information to the learners is a very good help to improve their understanding of the text, and thus, enhance the pedagogical effect of the activities carried out (Lazar 1993: 38). There exist several ways of presenting this information, as a mini lecture, as a reading or listening comprehension or as a research project for students to implement (Lazar1993: 38).

2. What is the historical setting/ period implied by the story?

3. What do the following characters/or setting symbolize?
a. Animals
b. Napoleon and Snowball
c. Manor Farm
d. Benjamin and Boxer

4. What is the central theme of this novel? Locate the commandment, which reveals it.

\section{Local Analysis}

Read chapter one of Animal Farm. Record new vocabulary and a summary in your reading journal, then answer the following questions for discussion.

1) Make a list of characters. Who do you think will be the most important characters? Why?

2) What does Major say about the relationship between animals and humans?

3) What is the importance of Major's dream? Why do you think the song is significant?

a) All the class, think of some literary expressions that reflect the themes of the novel.

b) Animal Farm is a novel of satire that ridicules, War, oppression, despotic governance, injustice, and tyranny, are some of the messages the novel attempts to transmit for the reader. Find with your partner the passages, metaphors or allusions in the novel that mostly disclose those messages for you or the passages the novelist tried to reveal those mentioned themes.

c) Try to find, with the use of a dictionary, the opposites of the words you used to define the feelings you got when reading Animal Farm. With these exercises, we use the recurrent allegory of the novel and the repeated allusions to oppression and injustice to develop the lexical competence of our students. Vocabulary exercises base here on the themes of cold war or wars of ideas and injustice practices which will, no doubt, make the learner interact in the classroom and in the group.

4) Round all regular verbs that you find and underline irregular ones. Establish the tense they are in (simple past, present perfect, conditional, etc.) and try to determine their function. Do the same with the modal verbs you encounter in your reading. This is grammar practice.

5) Practice reading aloud some extracts of the novel in small groups. What do you notice about the formation of the sentences and word use?

6) Think with a partner of things that make you feel sad and that make you frightened. Write them down in a list and write simple sentences with those words or expressions. Learners may write down things such as war, poverty, violence, or abuse

7) What changes have the years brought to the farm?

8) How does Orwell make fun of bureaucracy?

9) What drastic actions do the pigs use to shatter the animals' complacency?

10)All seven commandments are erased. What is the new commandment and how has it been true from the beginning?

11)At the conference with neighboring farmers, what new changes does Napoleon point out?

\subsubsection{Writing}

This section bases on the idea that through reading, writing abilities can also improve. It is important that we help our students to develop their writing skills in the foreign language.

1) Write a brief book report of Animal Farm based on the following prompt

- Title

- Central theme and major literary devices 


\section{International Journal of Science and Research (IJSR) \\ ISSN (Online): 2319-7064}

Index Copernicus Value (2015): 78.96 | Impact Factor (2015): 6.391

- Major characters

- Plot summary

2) Translate the hymn "Beasts of England" which occurs towards the end of chapter one, in to Amharic.

3) What do you think the author looked like? With a partner list a series of characteristics you think he may have had, both physically, you may even draw him, and mentally. Think of where he may have been born, what his occupation might have been, apart from writing novel.

4) Then, invent and write a biography for the author. The list of activities that could be included in this section is immense. We can think of selecting a word from the novel, elaborate a semantic family and create a novel out of them, completing parts of the novel, write a critic of the novel and so on (see Maley and Duff 1990, Carter and Long 1991, Collie and Slater 1994, Maley 1996 for further ideas of activities).

\subsubsection{The Experimenting}

This as a further section can be carried out by implementing a comparison of the novel of George Orwell, with some previous novels to see the differences at the thematic (symbols, conventions, and topics) and structural levels. The implementation of these activities can extend over one class period, but as the researcher has already said above, this intends to be an outline of suggestions to use the novel, "Animal Farm", as a resource for the teaching of English as a foreign language within the principles of the communicative approach. These lay importance on the development of social competence, of showing our students how to communicate in real life situations in the foreign culture and in the foreign language. The teacher has the responsibility of guiding her/his students to "learn to learn". This refers to the capacity of students to develop their own learning, their autonomy as language learners, and also why not, help them to distinguish by their own on the literary quality of a work.

\section{Conclusion}

This paper has examined a possible application of the novel, "Animal Farm", to the English as foreign language classroom. After having stated the increasingly popular use of literature in the foreign language classroom, a justification of the selection of the novel Animal Farm has followed. Both formally and thematically it is an interesting novel, its strong motivational power cannot be denied, the novel also displays real, current language, which is, from the point of view of the methodological approach (communicative approach) extremely important. In addition, the novel under discussion is culturally, historically and literary relevant, for which its use and study called on. Furthermore, the novel employs memorable characters, and literary devices that make it an enjoyable piece of literature, which learners will be pleased to read. With the proposal of activities, it has been seen that working on such a novel, not only literary competence can be developed, but also lexical, syntactic and social-communicative competence. If the activities and their implementation are appropriate, Animal Farm is a useful tool in EFL classrooms.

\section{Recommendation}

The teacher has an important role in teaching English as foreign language through literature. First, he/she should determine the aim of language teaching in relation to the needs and expectations of the students. Second, he/she should select the appropriate language teaching method, teaching techniques, and classroom activities. Then, the teacher should select the literary texts relevant to the aim and the objectives of his/her teaching. While selecting literary texts to be used in language classroom, the students' language proficiency, interests, age, sex, etc should be taken into account in order not to bore students with inappropriate materials. At advanced levels, students should be given literature in its original form so that they can develop their literary competence in the target language. To put it another way, students learn practically the figurative and daily use of the target language in the literary texts. Observing how characters in a novel use figures of speech, such as simile, metaphor, allegory, metonymy, etc so as to express their communicative intention, EFL students learn how to write in English more clearly, creatively, and powerfully. Teachers should try to teach basic language skills as an integral part of oral and written language use, as part of the means for creating both referential and interactional meaning, not merely as an aspect of the oral and written production of words, phrases and sentences.

\section{References}

[1] Adams, M. J. (1990). Beginning to Read: Thinking and Learning about Print. Cambridge, MA: MIT Press.

[2] Brumfit, C.J. and A. C. RONALD, eds. 1986. Literature and Language Teaching. Oxford: Oxford University Press.

[3] Carter, R. and M. Long, eds. 1991. Teaching Literature. London: Longman.

[4] Cassany, D. 1999. Construir la escritura. Barcelona: Paidós Comunicación.

[5] Coady, J. 1997. "L2 vocabulary acquisition through extensive reading". Second Language Vocabulary Acquisition. Ed. J. COADY and T. HUCKIN. Cambridge: Cambridge University Press. 225- 237.

[6] Collie, J. and S. Slater, eds. 1987. Literature in the Language Classroom. Cambridge: Cambridge University Press.

[7] Custodio, B. and M. Sutton. 1998. "Literature-Based ESL for Secondary School Students" in TESOL Journal. Vol 7, No.5, p.p: 19-23.

[8] Duff, A. and A. Maley. 1990. Literature. Oxford: Oxford University Press. 17

[9] Darian, S. G. (1972). English as a Second Language: History Development and Methods of Teaching. Norman, OK: University

[10] Grabe, W. and F. Stoller. 1997. "Reading and Vocabulary Development in a Second

[11]Language: A Case Study". Second Language Vocabulary Acquisition. Ed. J. Coady and T. Huckin. Cambridge: Cambridge University Press. 98-122. Grellet, F.1981. Developing Reading Skills. Cambridge: Cambridge University Press

[12] George Orwell's . 1945. "Animal Farm”. 


\section{International Journal of Science and Research (IJSR) \\ ISSN (Online): 2319-7064 \\ Index Copernicus Value (2015): 78.96 | Impact Factor (2015): 6.391}

[13] Krashen, S. 1989. "We Acquire Vocabulary and Spelling by Reading: Additional Evidence for the Input Hypothesis". The Modern Language Journal 73, 4: 440464.

[14] Krashen, S.(1982). Principles and Practices in Second Language Acquisition. Oxford: Pergamon.

[15]Lazar, G. 1993. Literature and Language Teaching. Cambridge: Cambridge University Press.

[16] Maingay, S. 1983. Making Sense of Reading. Hong Kong: Nelson Harrap.

[17] Mckenna, M. C., \& Stahl, S. A. (2003). Assessment for Reading Instruction. New York: Guilford Press.

[18] Mckay, S. 1986. "Literature in the ESL Classroom." Literature and Language Teaching.

[19]Ed. C.J. Brumfit and R.A. Carter. Oxford: Oxford University Press. 191-198.

[20] Maley, A. 1996. "That's for your poetry book!". Language, Literature and the Learner.

[21]Ed. R. Carter, and J. Mcrae. London: Longman. 100114.

[22] Obediat, M. 1997. "Language vs. Literature in English Departments in the Arab World" in English Teaching Forum.

[23] Paribakht, T.S. and M. Wesche. 1997. "Vocabulary enhancement activities and reading for meaning in second language vocabulary acquisition". Second Language Vocabulary Acquisition. Ed. J. Coady and T. Huckin. Cambridge: Cambridge University Press. 174200.

[24] Ramsaran, S. 1983. "Poetry in the language classroom". ELT Journal 37, 1: 36-43.

[25] Reid S. (2002). Book Bridges for ESL students: Using Young Adult and Children's Literature to Teach ESL. Lanham, MD: Scarecrow Press.

[26] Spack, R. 1985. "Literature, Reading, Writing, and ESL: Bridging the Gaps" in TESOL Quarterly. Vol 19, No.4, p.p: 703-721.

[27] Stern, S. 1991. "An Integrated Approach to Literature in ESL / EFL" in Teaching English as a Second or Foreign Language. ed. Murcia, M. Boston: Heinle \& Heinle Publishers. 